\title{
Discussion on Classroom Teaching Strategies of Basic Accounting in Higher Vocational Colleges Based on SPOC
}

\author{
Peng Xifeng, a \\ ${ }^{1}$ School of Jiangsu Vocational College of Finance and Accounting, Lianyungang 222061, China \\ ${ }^{a} 627868828 @ q q . c o m$,
}

Keywords: SPOC; basic accounting in higher vocational education; classroom teaching strategy

Abstract: Compared with traditional teaching and admonishing, higher vocational basic accounting classroom teaching based on SPOC is conducive to the improvement of the quality of education, and its teaching strategy is of great significance to improve the status quo of basic accounting classroom teaching in higher vocational education.

\section{Introduction}

In recent years, with the wide application of information technologies such as cloud computing, big data, "Internet+" and mobile technologies, and smart classrooms, the classroom teaching environment in higher vocational colleges has been completely improved, and the classroom teaching mode has been strongly impacted.

SPOC (Small Private Online Course) was proposed after M00C. It is an online small-scale classroom teaching mode that integrates online teaching platform with physical classroom teaching, including online media teaching environment, online media teaching tools and teaching management. Compared with the traditional teaching model, the introduction of SPOC into the teaching of higher vocational colleges will change the original teacher teaching model and student learning model. Focusing on teaching in the main field of teaching, this article will combine SPOC to explore the classroom teaching strategies for higher vocational basic accounting.

\section{The Status Quo of Basic Accounting Classroom Teaching in Higher Vocational Education}

The "Basic Accounting" course is the first professional basic course in the accounting profession of higher vocational education. It is both theoretically and practically strong. The current classroom teaching has the following characteristics. 


\subsection{Teaching methods and means need to be continuously updated}

With the popularization of information-based teaching equipment, such as the Internet, mobile devices, and smart classrooms, most of the higher vocational colleges' basic accounting classroom teaching is still centered on the teacher. Compared with the PPT-based single instruction mode, there is no social experience. For beginners, there is a certain degree of difficulty in understanding these abstract accounting theories, and the effectiveness of classroom teaching is greatly reduced.

\subsection{Teaching platform and resources need to be established and improved}

At present, higher vocational colleges use the campus network platform to develop some online teaching resources, teaching websites and online courses. Many higher vocational colleges started the construction of basic accounting online courses, but the teaching resources are relatively simple in form, simple to produce, the content of the curriculum is comprehensive and update speed, the diversification of resources, the characteristics of the curriculum, there are some problems, far from meeting the actual needs of teaching.

\subsection{Teaching content and work tasks need to be integrated}

The basic accounting of higher vocational education is the carrier of accounting "basic skills, basic theory, and basic knowledge". It selects and organizes curriculum content according to the work tasks of junior accounting positions. However, most of its practical teaching is based on the requirements of training materials for students to fill in the original vouchers, prepare accounting vouchers, register daily ledgers and subsidiary ledgers, prepare balance sheets and profit statements, and work processes and duties involving businesses in manufacturing enterprises. The lack of a three-dimensional understanding of the approval process, etc., is only a matter of passive mechanics, and the teaching content and tasks need to be further integrated.

\subsection{Self-study needs continuous improvement}

Most higher vocational students graduate from junior high school (specialty is a high school graduate) and have difficulty understanding the abstract theory of basic accounting. If practice teaching is not well coordinated, students are prone to difficulties, resist emotions, have low interest in learning, and lack active learning.

\section{Analysis of Classroom Teaching Based on SPOC}

SPOC, the small-scale private online course, is a typical school-based curriculum teaching paradigm in the post-M00C era. SPOC-based courses have the advantage over traditional classrooms.

\subsection{Teaching content design is more attractive}

First of all, SPOC restricts the learners involved. Teachers have a certain understanding of the number of learners, learners' needs, and the characteristics of different learners. They are more focused on the selection and design of teaching content and focus on learners' needs and curriculum. The design and teaching resources are presented in the form of micro-courses, videos, animations, etc., which increase students' interest in learning and increase the attractiveness of the course itself. 


\subsection{Teaching methods are more flexible and diverse}

Compared with traditional classroom teaching, most students like online classrooms. Based on SPOC, vocational foundation accounting teachers can use the online teaching platform to organize classroom teaching and make full use of online teaching resources to achieve a combination of online learning and offline learning. Classes and videos express knowledge points, relied on the interaction of platform discussion areas and the arrangement of online learning tasks. This real-time feedback and individualized teaching information is conducive to teaching students in accordance with their aptitude and greatly improves the efficiency and quality of classroom teaching.

\subsection{Teaching evaluation is more three-dimensional and comprehensive}

Based on the mixed mode of SPOC online learning and offline learning, it is easy to understand the learner's learning process and learning effect through platform data parameter analysis, and teaching evaluation is more diversified from students' participation to the submitted results. The main body of evaluation is more comprehensive from the teacher-student assessment, the student-to-student assessment to the self-assessment, and the assessment dimension relates to the learner's cooperation ability and learning ability, and the evaluation mechanism is more perfect.

\section{Strategy of Basis Accounting Classroom Teaching in Higher Vocational Education Based on SPOC}

\subsection{Platform resources construction}

Based on the continuous improvement of the quality of SPOC higher vocational basic accounting classroom teaching, the construction of platform resources is the premise and the key. The basic practical characteristics of the basic accounting curriculum, the use of the platform can provide a very rich source of teaching resources, can also simulate the display of accounting work process. During construction, the teaching team should cater for students' recognition of online video from the perspective of the learner, and design the teaching content of the basic accounting as a video of the embedded questions and checkpoints according to the degree of difficulty and importance of the knowledge points. The account vouchers are designed for multimedia presentations such as videos, animations, micro lessons, etc. At the same time, the corresponding PPTs, cases and related exercises and test questions are produced. During construction, the teaching team considers inspiring different learners' interest in learning, optimizing design, and platform resources to meet the needs of different learning bases and different learning objectives. Based on SPOC vocational basic accounting curriculum resources:

Table 1

\begin{tabular}{|c|c|}
\hline Course resources & $\begin{array}{c}\text { Basic accounting curriculum standards, basic accounting electronic teaching plan, } \\
\text { teaching PPT }\end{array}$ \\
\hline Standardized resources & Micro class, video, animation, etc. \\
\hline Dynamic data & Accounting job responsibilities and environment, typical cases, etc. \\
\hline $\begin{array}{c}\text { Professional resources } \\
\text { resources }\end{array}$ & $\begin{array}{c}\text { Accounting voucher training, accounting books training, accounting statements } \\
\text { training, etc. }\end{array}$ \\
\hline Diversified resources & Exercise bank, test bank, text, pictures, etc. \\
\hline
\end{tabular}




\subsection{Flip classroom}

Through the analysis of the situation of higher vocational students, the use of SPOC platform for "pre-class - in-class - after-class" three stages of flip teaching. Before class preparation, teachers sort out teaching content, design explanation methods, set learning requirements, create video resources and publish learning task lists online, and pay attention to students' online learning situations before entering classroom teaching, and prepare lessons accordingly. Students participate in online discussions based on the online tutoring task list to prepare for in-depth learning in the classroom. The stage of classroom implementation is a phase of face-to-face discussion and exchange of doubts between teachers and students. Teachers can flexibly adopt various forms such as individual tutoring, group discussion, group report, and teacher-student commentary on content difficulties, common problems, and students' doubts. They advocate classroom-based self-inquiry, active learning, and collaborative communication. The post-construction phase is to consolidate and test the entire learning task. Students complete homework assignments and unit tests on the SPOC web platform and provide timely feedback. Teachers and students interact in real time. The flip classroom mode is as follows:

Table 2

\begin{tabular}{|c|c|c|c|}
\hline Teaching session & Teacher & Interactive way & Student \\
\hline $\begin{array}{l}\text { Pre-class } \\
\text { preparation }\end{array}$ & $\begin{array}{c}\text { Upload courseware, } \\
\text { video, tutorials, and } \\
\text { other course } \\
\text { resources, discuss } \\
\text { online; understand } \\
\text { student knowledge } \\
\text { before class }\end{array}$ & $\begin{array}{c}\text { SPOC network } \\
\text { platform exchange }\end{array}$ & $\begin{array}{l}\text { Watch instructional } \\
\text { videos, review } \\
\text { related learning } \\
\text { resources, complete } \\
\text { tutorials, and } \\
\text { participate in online } \\
\text { discussions }\end{array}$ \\
\hline $\begin{array}{c}\text { Classroom } \\
\text { implementation } \\
\text { phase }\end{array}$ & $\begin{array}{l}\text { Organize students } \\
\text { to discuss and } \\
\text { discuss problems } \\
\text { and common } \\
\text { problems in groups; } \\
\text { individual tutoring; } \\
\text { personalized } \\
\text { guidance; } \\
\text { knowledge } \\
\text { summarization }\end{array}$ & $\begin{array}{c}\text { Face-to-face } \\
\text { classroom } \\
\text { communication }\end{array}$ & $\begin{array}{l}\text { Discussion and } \\
\text { exchange to } \\
\text { complete classroom } \\
\text { tasks; self-inquiry } \\
\text { and assist in } \\
\text { learning; } \\
\text { presentation of } \\
\text { results }\end{array}$ \\
\hline $\begin{array}{c}\text { Consolidation after } \\
\text { class }\end{array}$ & $\begin{array}{l}\text { Post-class } \\
\text { assignments, unit } \\
\text { tests; summary, } \\
\text { evaluation }\end{array}$ & $\begin{array}{c}\text { SPOC network } \\
\text { platform exchange }\end{array}$ & $\begin{array}{c}\text { Complete } \\
\text { homework } \\
\text { assignments, unit } \\
\text { tests; reflect, } \\
\text { summarize }\end{array}$ \\
\hline
\end{tabular}

\subsection{Discussion area for interactive teaching}

In the traditional basic accounting classroom teaching activities, most of them are taught by teachers. The students' enthusiasm for learning and active participation are limited. The online teaching platform based on SPOC is interactive and open. It can establish a course discussion area to discuss the theoretical learning content, single training operation and cross-curricular knowledge 
development issues. Teachers and students can initiate discussions at any time. Arrange teaching assistants or team members to provide regular guidance and answers to student discussions and questions. At the same time, by setting up more flexible and interactive channels and changing assessment methods, students are encouraged to participate in the course discussions, so that teachers and students, students and students communicate more frequently, feedback is more timely, and the initiative of learning is returned to the students. Through on-line interactions, the optimization of the classroom discussion below the line, improve the learning effect.

Based on SPOC Higher Vocational Fundamental Accounting, online teaching strategies are integrated into classroom teaching. In order to improve the overall effectiveness of basic accounting courses and promote student self-learning, an open and shared classroom model is constructed.

\section{Acknowledgements}

Fund Project: Jiangsu University of Philosophy and Social Sciences Research Project “The Practical Study of SPOC-based Hybrid Teaching in the Era of Big Data: Taking the Basic Accounting Course in Higher Vocational Colleges as an Example” (No. 2017SJB2016).

\section{References}

[1] Wang Pengjiao, Duan Tingting, Cai Yunan et al. SPOC-based flipped classroom instructional design model applied in open university [J]. China Electrification Education, 2015(12): 79-81

[2] Zeng Xing, Li Guiping, Zhou Qingping. From MOOC to SPOC: A Deep Learning Model Construction [J]. China Electro-Technical Education, 2015(11):28-34.

[3] Huang Guangfang, Wu Hongyan et al. The practice and research of effective teaching of SPOC in ubiquitous learning environment[J]. Research in Audio-Visual Education, 2016(5):50-57.

[4] Yan Juanjuan, Chen Chao. Explore the function and implementation of the school's SPOC teaching platform [J]. Education and Teaching Forum, 2017(8):6-8.

[5] Chen Ran. The new model of mixed learning in colleges supported by SPOC [J]. Journal of Jiangsu Open University, 2015, 4. 